\title{
Transfer of Corporate Seat in EU: Recent Developments
}

\author{
By Dubravka Aksamovic*
}

\begin{abstract}
Transfer of corporate seat has been important legal topic in EU law ever since 1980's. While it was clear from the wording of the very first EEC treaties, that companies should benefit from a freedom to establish themselves in another Member State, the extent of this freedom was, more or less, unclear. Some useful guidance with regard to the issue when and under what circumstances a company can transfer its corporate seat and its activities to another Member State, have been given by the ECJ. Every new Court's decision regarding transfer of corporate seat (such as ECJ decisions in case Centros, Inspire Art, Überseering, Daily Mail, Cartesio) had huge echo among corporate lawyers and business and were analysed in the smallest details. The most recent ECJ decision in Polbud case again showed that transfer of corporate seat is topic that still raises number of legal questions. In that sense, paper will analyse relevant EU legislation applicable to corporate mobility. It will particularly focus on new proposal of the Directive 2017/1132 on cross-border conversion, mergers and divisions and possible impacts of that Directive to corporate mobility. Special attention will be given to the ECJ ruling in Polbud case in which ECJ had to decide on delicate question as to whether or not companies should be allowed to "change nationality".
\end{abstract}

Keywords: Companies, Mobility Transfer of Corporate Seat; Directive on Cross Border Conversion; Mergers and Divisions.

\section{Introduction}

The idea of free movement of companies on the internal market is not new. Free movement of companies is clearly given Treaty right ${ }^{1}$. Yet, more than a quarter of century after the ECJ rulings in Daily Mail ${ }^{2}$ and Centros ${ }^{3}$, some of the first prominent EJC decision concerning corporate mobility, and after numerous EU Commissions attempts to provide systematic solution on the problem of corporate mobility, cross-border mobility of companies remains unresolved issue. Moreover, large number of EU countries still show great level of hostility towards companies' migration and do not allow companies to move abroad through process of conversion or any other way, without previously being dissolved in country of origin. As a result, companies wishing to move to another Member state, although

\footnotetext{
"PhD, Associate Professor, Head of Department of Business Law, Faculty of Law, University of Osijek, Osijek. Croatia. Email: daksamov@pravos.hr.

${ }^{1}$ Article 49 and 54 of the TFEU guarantee freedom of establishment of all companies and firms.

${ }^{2}$ The Queen v H. M. Treasury and Commissioners of Inland Revenue, ex parte Daily Mail and General Trust plc. Case 81/87. European Court Reports 1988 -05483. ECLI identifier: ECLI: EU:C:1988:456

${ }^{3}$ Centrols Ltd and Erhvervs-og Selskabsstyrelsen, Case C212/97, ECR, I-1459. Judgement of 9 March 1999.
} 
cannot be absolutely prevented from right to move, face financial, administrative and legal obstacles. Such situation has negative impact on EU integration and jeopardises basic ideas on which EU was built upon.

This legal issue itself would not be so controversial if, beyond the technical discussion, there were no important political and economic interests at stake ${ }^{4}$. Under the current Member States legal regime, all cross-border operations are rather costly. According to the estimations provided in Study on the cross-border transfers of registered office and cross-border division of companies ${ }^{5}$ a crossborder transfer of registered office costs in average at EU level, between 20,000 and 40,000 euros, while for example a cross-border division costs in average at EU level, between 55,000 and 70,000 euros per operation ${ }^{6}$. These costs vary from state to state and they depend on the type and size of company, hosting and home country, current procedures, and registration fees ${ }^{7}$. These costs are typically associated with the attorney's fees, costs related to the execution of the transfer (production of documents, organisation of general meeting, etc.) and registration costs $^{8}$.

However, statistical data provided in the second report on Cross-border Mobility in the $\mathrm{EU}^{9}$ shows that despite numerous obstacles and high costs associated with the transfer of corporate seat through merger or otherwise, number of European companies moving from one Member State to another is in constant increase. Accordingly, in four year period, from 2008 to 2012 there were totally 1227 transactions that have resulted in transfer of corporate seat, what is approximately 306 transactions annually, while in five years period from 2013 until 2018 there were totally 1936 transactions that have resulted in transfer of corporate seat, or approximately 387 transactions annually ${ }^{10}$. As we can see, on annual level number of transactions increased for almost $25 \%$. That is not negligible number. Those figures should be taken seriously. They also oblige EU to act and to provide for a workable solution for those companies who wish to move from one Member State to another.

So far, EU Commission's attempts to regulate analysed issue brought only partial success despite the fact that EU got overwhelming support for enactment of legal instrument which would regulate cross border mobility of companies ${ }^{11}$.

For example, in 2004 the Commission conducted public consultation on the Future of EU company law where significant majority of $68 \%$ of the consultation participants were in favour of enacting directive that would regulate cross border transfer of companies' seat ${ }^{12}$. Then again, the Commission carried out several public consultations in 2012, 2013, 2015 and 2017 asking all interested stakeholders

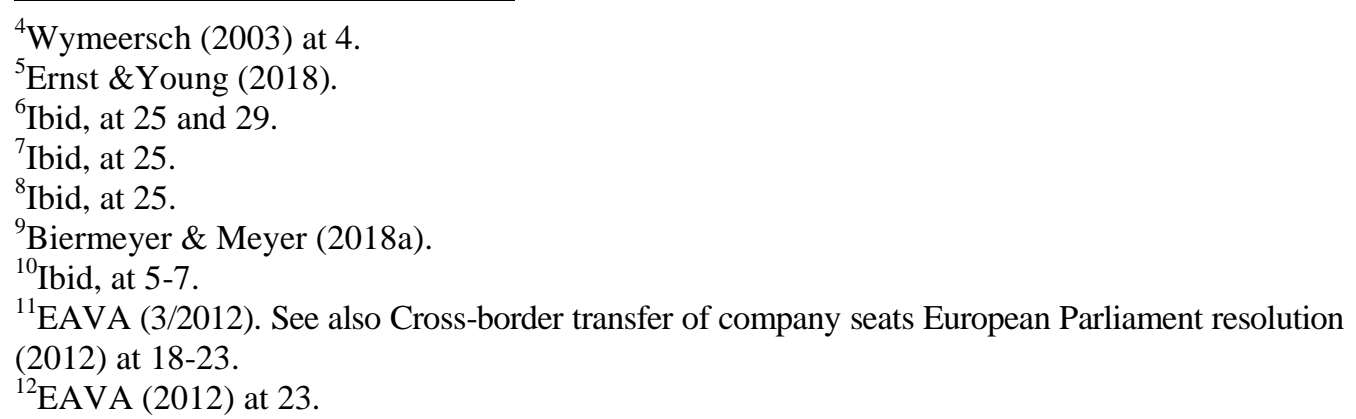


whether regulation of cross-border migration of companies is needed ${ }^{13}$. The majority of respondent supported Commission's initiative to adopt regulation which would enable simple, transparent and cost-effective relocation of company from one Member State to another. However, despite incontestable support to the Commission and Commission's really intensive legislative activities, we still do not see the end and final outcome of all those efforts. An issue on companies' migration on EU level looks like a never-ending story. In that sense, in lines that follow author will firstly give brief overview on the most relevant EU documents dealing with companies' migration. Special attention will be given to the most recent developments.

\section{Transfer of Corporate Seat- Old Story with New Beginning or a Never Ending Story?}

The issue on corporate mobility on EU level is as old as EU, although this topic didn't gain much public attention before 1990'. Many would agree that problem of companies mobility came in public focus after the ECJ decision, firstly in Daily Mail in 1988, and then again in Centros case in 1999. Since then, an interest for this topic was quite uneven, sometimes is increasing, usually after some ECJ decision, and then again, it was decreasing. Things started to change after year 2000, when discussions on corporate mobility has become a hot topic ${ }^{14}$.

First Commission's serious attempt ${ }^{15}$ to address the problem of corporate mobility came in form of proposal for the $14^{\text {th }}$ Company Law Directive, Directive on the cross-border transfer of company's registered office or de fact head office to another Member State ${ }^{16}$. The first draft proposal was proposed by the Commission in 1997. ${ }^{17}$ After several public consultations during early 2000's and despite clear EU Parliament position that such legislative instrument is welcomed and needed, EU Commission in 2007 decided not to make any legislative proposal and reserved the right to take further action with regard to the question of crossborder transfers of corporate seat ${ }^{18}$. If enacted, that Directive would prevent most

\footnotetext{
${ }^{13}$ See e.g. European Commission (2013). Feedback Statement, Summary of Responses to the Public consultation on Cross-border transfers of registered office of companies, September 2013, Ref. Ares (2016) 158996-12/01/2016.

${ }^{14}$ See e.g. Frost (2005); Lennarts (2008); Frada de Sousa (2009).

${ }^{15}$ With regard to analysed issue it should be mentioned that starting from early 70's EU produced several legislative acts which, directly or indirectly, addressed the problem of transfer of corporate seat. For example, in 1985 European Parliament adopted Regulation No 2137/85 on EEIG, than in 2001 in enacted Regulation No 2157/2001 on the Statute for European Company (commonly known as Societas Europea) and lastly in 2003 it enacted Regulation No 1435/2003 on the Statute for a European Cooperative Society. Although all three mentioned regulation deal with some aspects on corporate mobility, none of those documents were really enacted with the purpose to resolve open issues that occur in practice with regard to transfer of corporate seat or cross-border companies' migration.

${ }^{16}$ Cross-border transfer of company seats (2012) at 18-23.

${ }^{17}$ Proposal (1997).

${ }^{18}$ EAVA (2012) at 10.
} 
of the problems that still occur in practice as a result of different Member State legislations and practices with regard to transfer of corporate seat ${ }^{19}$.

However, there no signals from the Commission that it is likely that it will happen in near future. Nonetheless, although $14^{\text {th }}$ Company Law Directive never came in force, it is not a document without any significance. Firstly, it prompted debates regarding companies mobility on EU level, it provided at least draft framework on the issue that it should be dealt with, and lastly, it made obvious that cross-border company mobility is no longer in the exclusive domain of national authorities ${ }^{20}$.

On the other hand, unlike the Commission's attempts to regulate cross-border transfer of companies' seat, Commissions efforts in regulation of (cross-border) mergers were much more fruitful. Already in 1978 Directive 78/855/EEC concerning mergers of public limited liability companies ${ }^{21}$ came into force. However, it should be emphasised that this Directive did not address the issue of cross-border mergers. Therefore, a crucial piece of legislation which would enable cross- border transfer of corporate seat through merger operations on EU level was missing all the way until year 2005 when EU Council and Parliament adopted Directive on Cross-border Mergers. This Directive has developed quite complex mechanism in respect to cross-border mergers and divisions ${ }^{22}$. It ushered in a new age for cross-border mergers ${ }^{23}$. Data show that after enactment of this Directive, merger activity has increased by $173 \%^{24}$. However, as anticipated, 2005 Merger Directive did not provide adequate legal solutions for all situations that emerged in cross-border merger practices. It was envisaged as a "living document" subject to review $^{25}$. Accordingly, following comprehensive public consultations regarding existing barriers to cross-border operations and about the amendments that needed to be made to existing legislation, based on gathered information in 2017 Commission submitted a proposal for amending the 2005 Merger Directive. A new Directive (EU) 2017/1132 of the European Parliament and of the Council relating to certain aspects of company entered into force on 14 June 2017. Besides changes with regard to regulation of merger procedure, this Directive also codified several earlier Directives as a part of Company Law Modernisation Package $^{26}$. Directive 2017/1132, among others, created a procedure for crossborder mergers and divisions of Limited Liability Company.

\footnotetext{
${ }^{19}$ According to the research provided by the DG Just in document called: Study on the cross-border transfers of registered office and cross-border divisions of companies, Member States legislation and practices with regard to the possibility of cross-border mergers, divisions or conversion significantly differ. Accordingly, specific national procedures in relation to cross-border transfers exist in Cyprus, Czech Republic, Denmark, Malta and Spain, while for example Member States that do not authorise the transfer of registered office are Croatia, Finland, Ireland, Lithuania, Romania and UK. See more at Ernst \& Young (2018).

${ }^{20}$ Rammeloo (1999) at 110.

${ }^{21}$ Third Council Directive (1978) at 36-43.

${ }^{22}$ See Biermeyer \& Meyer (2018b) at 4.

${ }^{23}$ Study on the Application on the Cross-Border Mergers Directive (2013) at 5.

${ }^{24}$ Ibid, at 5 .

${ }^{25}$ This conclusion can be supported by the Article 18 of the 2005 Merger Directive which called for review of a Directive 5 years after final date of transposition.

${ }^{26}$ Proposal (2017).
} 
However, this Directive did not last long. Less than a year after its enactment, the Commission submitted a new proposal to amend above mentioned Directive. It is significant that new Proposal came immediately after another EJC's milestone decision in so called Polbud case ${ }^{27}$ what is not just pure coincidence. Paper will further highlight the basic features of Commission's Proposal on the Directive Cross-Border conversions, mergers and divisions.

\section{New Proposal for a Directive Conversion, Mergers and Divisions- Objectives and General Approach}

New Proposal on Directive as regards cross- border conversions, mergers and divisions is rather complex and somewhat unsystematic legal document. It is surprisingly large document ${ }^{28}$, particularly in light of the fact that the issue of cross-border mergers and divisions have been previously regulated by earlier Directive and that, in that sense, the proposed text is not a new directive, but just an amendment to an existing one.

If we look at the structure of the Proposal, it is noticeable that the Proposal consists of few parts. It starts with a lengthy explanatory memorandum, where Commission provides reasons for and objectives of the Proposal. After this long introduction follows the central part of Proposal where in two chapters, Chapter I and Chapter IV, Commission proposes regulatory framework for three different types of cross-border business operations, cross-border conversion (article 86a to 86u), cross- border mergers, and cross-border divisions (article 160a to 160w).

While with regard to cross-border mergers, Proposal only improves and updates already existing rules of the Directive 2017/1132, with regard to crossborder conversions and cross-divisions Proposal introduces completely new rules. When (and if) new Proposal is adopted, a whole spectrum of cross-border legal operations will be offered to the European companies aspiring to move from one Member State to another Member State in search for better business opportunity or more favourable business environment. In further text paper will present main features of two new cross-border business operations, cross-border conversions and cross-border divisions.

\footnotetext{
${ }^{27}$ Judgment of the Court (Grand Chamber) of 25 October 2017.Proceedings brought by Polbud Wykonawstwo sp. z o.o. Request for a preliminary ruling from the Sąd Najwyższy.

${ }^{28}$ Proposal altogether has 127 pages. It contains very detailed 40 page long explanatory memorandum where Commission first provides for reasons and objectives of Proposal and then follows the text of proposed amendments to the current text of the Directive.
} 


\section{Cross-Border Conversions}

Proposal regulates only cross-border conversions ${ }^{29}$. In that sense it should be emphasised that "domestic" conversions are out of the scope of Proposal. In the Proposal, a cross-border conversion is defined as "an operation whereby a company, without being dissolved, wound up or going into liquidation, converts the legal form under which it is registered in a departure Member State into a legal form of a company of a destination Member States, and transfers at least its registered office into destination Member State whilst retaining its legal personality" ${ }^{30}$.

As we can conclude from above definition, main features of cross-border conversions are following: a) change of legal form, where a company established in accordance with the rules of one Member State converts in appropriate type of company of another Member State; b) transfer of economic activity, or /and registered office of converted company to destination Member State; c) converted company retains its legal personality since in case of conversion a company doesn't have to go through liquidation or other similar procedure in departure Member State. Although at the first glance it may seem that changes that occur in process of cross- border conversion are comparable to changes that occur in domestic conversion, a closer examination of domestic and cross-border conversion reveal that differences between these two conversions are significant.

Unlike domestic conversions, which do not bring radical changes to different stakeholders affected by conversion ${ }^{31}$, in case of cross-border conversion, besides change of legal form, what is a common feature of domestic and cross-border conversions, a converted company also changes its "nationality". The fact that a company through a process of conversion changes its nationality means that the legal entity after conversion will be governed by a different company law regime. For employees that means that companies' employees shall become employees of a foreign company, for shareholders it means that their rights in the company after conversion shall be decided in accordance of the legislation of destination Member State, and for creditors it means that they will face a new legal regime, the one of the destination Member State.

Although it does not necessarily mean that their rights will be automatically reduced or seized, and they may even would be better or improved in case destination Member State applies higher legal standards with regard to shareholders, employees or creditors rights, still it may bring some legal uncertainty and creates fear as regards what future brings to them after conversion.

\footnotetext{
${ }^{29}$ Companies' conversion is one of many business restructuring operations. It is such legal operation where company changes its legal form and continues to exist as a company of different legal form, without being dissolved.

${ }^{30}$ Article 86 b of the Proposal (2017).

${ }^{31}$ When conversion doesn't not include cross-border component it is not particularly intriguing operation. Except change of legal form, everything else stays more or less the same, employees keep their rights, and creditors automatically become creditors of converted company. There may be some differences with regard to ownership rights, but that issue will be resolved in process of conversion. Aksamovic, Simunovic \& Kuna (2019).
} 
This is mainly because of the fact that not all conversions are economically justified, but may be carried out with fraudulent intent ${ }^{32}$.

Being aware of the fact that certain percentage of cross-border conversions are merely artificial constructions, the Commission pays in the Proposal special attention to the protection of employees, creditors and shareholders as well as to ex ante and ex post control of conversion procedure.

\section{Conversion Procedure}

Conversion procedure is in the Proposal fairly detailed regulated. It is envisaged as structured and multi- layered procedure which ensures a scrutiny of the legality of the cross-border conversion, firstly by the competent authority of the departure Member State, and secondly by the competent authority of the destination Member State ${ }^{33}$. The first step in the procedure would be the preparation of the draft terms of the cross- border conversion and two targeted reports addressed to shareholders and employees on the implications that the cross-border conversion will have $\mathrm{e}^{34}$. Draft terms must be prepared by companies' management. It must contain all relevant information on proposed conversion based on which employees, creditors and other stakeholders will be able to determine how conversion will impact their position and rights ${ }^{35}$. Except for the stated purpose, specific value of the draft terms lays in the fact that it serves as a basis for the determination whether the intended cross-border conversion consitutes an artificial arrangement ${ }^{36}$. Besides preparing draft terms for conversion, management or administrative organ of the company will also have to prepare two separate reports explaining and justifying the legal and economic reasons for cross-border conversion. One report should be written for members of the company (shareholders) and the other on for the employees. ${ }^{37}$ In order to avoid abuses of accuracy of information provided in the draft terms and reports, Proposal prescribes that draft terms and reports have to be examined by an independent expert $^{38}$. Examination by an independent expert serves as an assistance to the competent authority of the departure MS to make a correct decision as to whether or not to issue the pre-conversion certificate on cross-border conversion ${ }^{39}$.

During the conversion proceedings, both mentioned documents have to be approved by the General Assembly before they are submitted, first, to the competent authority of departure Member State which is responsible to decide

\footnotetext{
${ }^{32}$ One of the biggest concerns associated with cross-border companies' migration is as to whether cross-border operation constitutes artificial arrangements. See, e.g. Cerioni (2010); Biermeyer \& Meyer (2018b).

${ }^{33}$ Proposal (2017) at 6.

${ }^{34}$ Ibid.

${ }^{35}$ Aksamovic, Simunovic \& Kuna (2019).

${ }^{36}$ Ibid.

${ }^{37}$ Art. 86e of the Proposal ${ }_{\text {, Rec. }} 11$ and 12, Art 86e(1) and 86f(1) of the Proposal; e.g. see Mörsdorf (2019) at 145.

${ }^{38}$ Aksamovic, Simunovic \& Kuna (2019).

${ }^{39}$ Rec. 13 of the Proposal. Independent experts are appointed by the competent authority of the departure MS. Art 86g (2) the competent authority of the departure MS appoints individual expert within 5 working days from the application for examination.
} 
whether to issue a pre-conversion certificate or not ${ }^{40}$. If after detailed scrutiny, the pre-conversion certificate is issued, it would be transmitted without delay to the competent authority of destination Member State. Destination Member State must carry out a scrutiny as regards that part of the procedure which is governed by the law of destination Member State and it must check whether converted company complies with provisions of its national law on the incorporation of companies. When all checks are done and if all requirements are met, a company would be registered in the register of a Member State of destination and de-registered in the register of the Member State of departure ${ }^{41}$. From the moment of registration in the destination Member State, conversion becomes legally effective. From that moment a company gets new "nationality" and becomes a company of a destination Member States, what can, as already said, cause fears and doubts as regards to the rights of employees, creditors or shareholders.

\section{Employees, Creditors and Shareholders Rights}

The Commission's concern for employees, creditors and shareholders rights is more than obvious. In the Proposal, Commission repeatedly emphasise that the main objectives of the harmonised rules for cross-border conversions are two-fold:

- enabling companies, particularly micro and small, to convert in an orderly, efficiently and effective manner, and

- protecting the most affected stakeholders such as employees, creditors and shareholders in a suitable and proportionate manner ${ }^{42}$.

Since detailed analysis of all rights granted to employees, creditors and shareholders is beyond the scope of this paper, here are few examples of the most important rights given shareholders, employees and creditors.

Quite expectedly, the largest number of rights relates to shareholders rights. Firstly, conversion procedure must be approved by shareholders at the General Assembly meeting. Before meeting, shareholders must be given a right to comment on draft term and to propose changes. They can also submit comments to the company and independent expert what may influence independent expert final report. Proposal doesn't prescribe required majority of shareholders for reaching the decision on conversion, however, it prescribes that all shareholders who voted against conversion have right to cash compensation. This right is also extended to shareholders who did not vote at all. Quite unusually, the Proposal prescribes that shareholders who decided to exit company and who accepted cash compensation have right to challenge the calculation of the amount of cash compensation before national court within one month of the acceptance of the offer. ${ }^{43}$ It is interesting that this opportunity is given to members even though they accepted the offer ${ }^{44}$.

\footnotetext{
${ }^{40}$ Proposal (2017) at 8.

${ }^{41}$ Ibid.

${ }^{42}$ Proposal (2017) at.12.

${ }^{43}$ Art $86 \mathrm{j}$ (5) of the Proposal.

${ }^{44}$ Aksamovic, Simunovic \& Kuna (2019).
} 
With regard to the creditors, they are also protected in various ways, since there is a risk that their interests will be adversely affected by the conversion, in particular, by being henceforth subject to less stringent rules in relation to capital protection and liability. ${ }^{45}$ For example, creditors, who find that their interests in the conversion are not sufficiently or adequately protected have right on administrative or judicial protection of their rights within one month of the disclosure. ${ }^{46}$ Moreover, Proposal also predicts that the Member States may require that the management of the company provide a declaration of accuracy reflecting the financial status of the company as a part of draft terms ${ }^{47}$. Creditors can also submit comments on draft terms and independent expert report to the company as well as to the competent authority ${ }^{48}$.

And lastly, the Proposal also prescribes mandatory employees participation in the company carrying out a conversion and provides mechanisms for protection of employees, since their rights are put at risk by the conversion procedure. In the first place, the rules on employee participation of destination MS applies must been followed, unless the rules of departure MS provides the same level of protection $^{49}$.

\section{Cross-border Divisions}

Besides cross-border conversion, Proposal further introduces a new legal framework for cross-border divisions. So far, EU legislation captured only rules on "domestic" divisions. Sixth Company Law Directive dealt with division of Limited Liability Company ${ }^{50}$; however rules on that Directive were inapplicable to cross-border divisions. Company division can typically take one out of two main forms, first is division by acquisition, and second is division by formation of a new company. Proposal regulates only division by formation of new company. Such approach is criticised as insufficient and unjustified, particularly because of that fact that cross-border divisions were already possible based on Treaties rules and ECJ rulings. According to the EJC decisions in Sevic ${ }^{51}$, Cartesio ${ }^{52}$ and Vale ${ }^{53}$, companies are allowed to enjoy a right to participate in cross-border division within a Member State to the same extent that the division is accepted by that Member State in its national law. However, despite this Court's attitude, in all EU countries which do not have explicit rules for cross-border conversion, and great

\footnotetext{
${ }^{45}$ Horak \& Dumančić (2017) at 725.

${ }^{46}$ Article 86k (2) of the Proposal.

${ }^{47}$ Article $86 \mathrm{k}$ of the Proposal.

${ }^{48}$ Article $86 \mathrm{~h}$ of the Proposal.

${ }^{49}$ Aksamovic, Simunovic \& Kuna (2019). See also: Art 86f and 861 (1) and (2) of the Proposal.

${ }^{50}$ Sixth Council Directive 82/891/EEC of 17 December 1982 based on Article 54 (3) (g) of the

Treaty, concerning the division of public limited liability companies, OJ L 378, 31.12.1982, p. 47-54.

${ }^{51}$ Sevic Systems AG, C-411/03, 13 December 2005.

${ }^{52}$ Cartesio Oktato és Szolgáltato bt, C-210/06, 16 December 2008.

${ }^{53}$ VALE Epitéci kft, C-378/10, 12 July 2012.
} 
majority of EU Member States don't have rules on cross-border division ${ }^{54}$, crossborder division of a company is either impossible, or if it is possible through indirect procedures ${ }^{55}$, than, it is extremely difficult and expensive.

Therefore, with regard to cross-border division, Proposal also aims at introducing harmonised procedure for cross-border divisions. However it simultaneously pays significant attention, as in case of cross-border conversion, to shareholders, creditors and employees rights.

Provisions relating to the procedure of cross-border divisions are largely inspired by the existing framework for cross-border mergers and cross-border conversions. Given the similar risks inherent to cross-border divisions as to crossborder conversions, the structured and multi-layered procedure as proposed for conversion would also be required for divisions ${ }^{56}$. The procedure for cross-border division follows closely existing one for cross-border conversion ${ }^{57}$.The first step in the procedure is drawing up of the draft terms and external experts report, disclosure of those documents to employees, creditors and shareholders, shareholders' approval at the General Assembly, examination of documents by the competent authority of the Member State of departure and then of the competent authority of the destination Member State. Last step is registration of the company in destination Member State.

Whilst the procedure of the division is largely similar to the procedure of conversion, situation is a bit different with regards to the rights of creditors, shareholders and employees. When a company divides itself into one or more companies, the creditors, employees and shareholders of the company will want to know whether they will be creditors, employees or shareholders in new company, formed by division or they will retain their rights and position in "old" company ${ }^{58}$. Creditors may particularly be concerned about financial stability and sustainability of new company which will have to pay debts when they become due ${ }^{59}$, while shareholder will be concerned whether after division the shares in a new company will worth less that shares in "old company". As regards to the employees, it is obvious that for some employees, notably for those who will continue to work in "old company", nothing will change after division. They will continue to work in same company and in the same country. On the other hand, some employees will be transferred in new company formed by division and they will face same consequences, risks and fears as employees in case of companies' conversion.

Abovementioned issues clearly indicate that with regard to protection of shareholders, employees and creditors rights, Proposal cannot follow identical approach as in case of cross-border conversion. Here are few examples of rules that Proposal prescribes in cross-border divisions and which are non-existent in regulation of conversion.

\footnotetext{
${ }^{54}$ Cross-border division are explicitly permitted only in the laws of Czech Republic, Denmark and Netherlands. Study on the cross-border transfers of registered office and cross-border divisions of companies, Ernst \&Young (2018) at 40 and 72.

${ }^{55}$ Ibid, at 73 .

${ }^{56}$ Proposal (2017) at.11.

${ }^{57}$ Alvarez (2018).

${ }^{58}$ Knapp (2018).

${ }^{59}$ Ibid.
} 
So, with regard to creditors, Proposal prescribes that when creditors claim is transferred to a recipient company, and if a creditor cannot obtain satisfaction form that recipient company, recipient company and divided company shall be jointly liable for that obligation ${ }^{60}$, even if such protection is not established under the national, Member State rules. Proposal further prescribes that all directors of dividing company have to make a declaration of solvency. In this declaration they will have to confirm that they are unaware of any reason why the dividing company and the recipient company will be unable to meet their liabilities when they fall due $e^{61}$.

With regard to employees, Article $160 \mathrm{n}$ deals with the participation of employees in management or supervisory boards. In principle, it prescribes that the employee participation in the recipient companies would have to follow the respective Member State rules, unless the national laws of Member State doesn't provide for same level of the employee participation in the company's management or supervisory organs as existing in the company being divided ${ }^{62}$. In case that as a result of national Member State rules number of employees in the company's management or supervisory organs decrease, the company will have to enter into negotiations with the employees to determine their participation in the recipient company. Such negotiations are obligatory ${ }^{63}$. Moreover, Proposal prescribes that recipient company will have to preserve at least for three years in substance the employees' participation rights in case of subsequent operations like mergers, divisions or conversions ${ }^{64}$.

Article 1601 provides for safeguards for shareholders. With regard to shareholders, differences in regulation of cross- border conversion and cross- border divisions are lesser. Like in case of cross-border conversion, in case of crossborder division shareholders are entitled to vote on draft terms, to suggest changes, to comment on the draft terms and lastly they are also entitled to exit rights and cash compensation. Members who want to keep their rights in the company can challenge the share exchange ratio which was suggested and explained in draft terms ${ }^{65}$.

\section{European Court of Justice - A Driving Force of EU Integration and Free Movement of Companies}

Commission's political battle for free movement of companies on European level would not have been possible without strong support of ECJ. Some authors stress that 'the biggest boost for companies' mobility did not come from the Commission, but from that other powerful EU institution, the European Court of Justice" ${ }^{, 66}$. Irrespectively as to whether we agree or disagree with above statement,

\footnotetext{
${ }^{60}$ Article $160 \mathrm{~m}$ of the Proposal.

${ }^{61}$ Knapp (2018).

${ }^{62}$ Proposal (2017) at 40.

${ }^{63}$ Proposal (2017) at 40.

${ }^{64}$ Proposal (2017) at 40.

${ }^{65}$ Article $160 \mathrm{~g}$ of the Proposal.

${ }^{66}$ Lennarts (2008) at 1.
} 
it is undisputed that many obstacles and barriers to cross-border mobility have been removed by ECJ, much before the Commission have finally reached political consensus on certain sensitive issue. This is definitely true as regards cross-border conversions. A Proposal for a Directive as regards cross-border conversions, mergers and divisions is Commission's reaction to ECJ decision ${ }^{67}$ in Polbud case $^{68}$. However, although Polbud case may have been a trigger to regulation of cross-border conversions and cross-border divisions on EU level, it is just one of many the ECJ's milestone decisions on the freedom of establishment. A number of earlier ECJ decisions, such as Centros, Inspire Art, Daily Mail, Vale and other pawed the way to Court's decision in Polbud.

\section{Polbud Case: Just another EJC Decision or a Step Closer to Final Solution for Companies' Migration?}

Polbud case concerns Polish company who decided to transfer its registered office to Luxemburg. Decision on transfer of company's registered office was brought by a resolution of extraordinary general meeting which took place on 30 September 2011. On the basis of that resolution, Polbud lodged a request for opening of a liquidation procedure in Polish commercial register. In 2013 Polbud transferred its registered office to Luxembourg and become Consoil Geothechnik Sarl. Following the transfer of registered office to Luxembourg, Polbud lodged an application at the Polish registry requesting its removal from Polish commercial register. The reason stated for the application was the transfer of the company's registered office to Luxembourg. The registry requested from Polbud to submit number of documents which a regularly required in case of winding up procedure. Polbud claimed that it this request is legally unfounded because it was not being wound up and because company continued to exist as a company incorporated under Luxembourg law. The Court did not accept Polbud's arguments and it refused Polbud's application for removal on the ground that the abovementioned documents have not been submitted ${ }^{69}$. Against that decision Polbud brought an action before national courts, firstly to the competent District Court and then an appeal to the competent Regional Court. In those proceedings, Polbud claimed that compliance with the requirements of the mandatory liquidation procedure laid down under Polish law was neither necessary nor possible, since it had not lost its legal personality ${ }^{70}$. Both Polish courts dismissed the action ${ }^{71}$. The third referring Polish court, the Supreme Court of Poland, decided to stay the proceeding and to refer following questions to the ECJ for a preliminary ruling ${ }^{72}$.

Firstly, the Polish Supreme Court asked whether freedom of establishment applies to the transfer of registered office, when there is no change in location of

\footnotetext{
${ }^{67}$ See Frazzani, Angelici,, Hoffmann, MmedicI \& Sciaudone (2018) at 25

${ }^{68}$ Polbud - Wykonawstwo sp. z o.o.,C-106/16, 25 October 2017.

${ }^{69}$ Poblud, points 7- 13 of the Judgement.

${ }^{70}$ Frazzani, Angelici, Hoffmann, MmedicI \& Sciaudone (2018) points 7-13 of the Judgement.

${ }^{71}$ Rammeloo (2018) at 89.

${ }^{72}$ Frazzani, Angelici, Hoffmann, MmedicI \& Sciaudone (2018) point 18 of the Judgement.
} 
its real head office and when company incorporated under the law of one Member State converts to a company of another Member State.

Secondly, the Polish Supreme Court asked whether national rules which prescribe that removal from the commercial register is possible only after mandatory winding up procedure are contrary to the freedom of establishment.

In short, on those questions the ECJ gave following answers. The EJC said that the transfer of the registered office of a company, where there is no change in location of real heads office, falls within the scope of freedom of establishment protected by EU Law ${ }^{73}$. Moreover, it said that it is not necessary for the company to pursue a "real business" in the Member State where it transfers its registered office $^{74}$.

With regard to second question, the ECJ held that Polish legislation which require mandatory liquidation of a company that wishes to transfer their registered office to another member State constitutes a restriction on freedom of establishment. With regard to that, the EJC also said that, while both Member States, of departure and of arrival may impose certain requirements, no unjustified restrictions can be imposed, even when the same are apt as protecting primarily interests such as protection of workers, creditors and shareholders ${ }^{75}$. For the end, the EJC concluded that a general requirement of winding-up a company before carrying out a cross-border conversion is an unjustified restriction to the freedom of establishment, and is not proportionate to the extent to attain shareholders, creditors and worker's protection ${ }^{76}$.

As we can see, in Polbud judgement the ECJ once again confirmed its general position that EU companies should not be prevented from right to move from one Member State to another and thus deprived from the right on the freedom of establishment. Innovative element in this decision, compared to Court's previous decisions, lies in the fact that it extended freedom of establishment on the situation of transfer of corporate seat without transfer of "real business". However, the special merits of Polbud and other ECJ decisions on companies' migration do not solely lay in the context of particular Court's ruling. Although every new Court's decision created another breakthrough in the domain freedom of establishment, the more important is political message that is send by the ECJ. Nonetheless, we all must be aware of Court's limitations. The Court itself cannot fill all loopholes in EU law or remove all contradictions that exist in the national laws of Member States. The Power of removing those obstacles lies in the hands of European Commission and European Parliament.

\footnotetext{
${ }^{73}$ Frazzani, Angelici, Hoffmann, MmedicI \& Sciaudone (2018) at10.

${ }^{74}$ Frazzani, Angelici, Hoffmann, MmedicI \& Sciaudone (2018) at.10.

${ }^{75}$ Ibid, at 10 .

${ }^{76}$ Ibid, at 14.
} 


\section{Conclusion}

Paper provides for a critical insight in the most recent developments regarding companies' migration in the EU. It examines major novelties in the new Commission's Proposal for a Directive as regards cross-border conversions, mergers and divisions. It describes political and economic context in which EU rules on companies' migration evolved as well as role of the ECJ in those processes.

Special attention is given to the Proposal's rules on cross-border conversions and cross-border divisions, in particularly rules that relate to the procedure of cross-border conversion and cross-border division. It also focuses on some of the most relevant issues regarding rights of shareholders, employees and creditors. Although paper doesn't go into detailed and deeper analysis of proposed legal solutions, the general impression is that the proposed procedure for cross-border conversion and cross- border division is quite robust and complicated and that there is a need for improvements and convergence of rules related to shareholders, employees and creditors rights.

Nonetheless, this doesn't bring into question necessity of enacting Proposal for a Directive as regards cross-border conversions, mergers and divisions. It is unquestionable as to whether such legal instrument is desirable or not. The new rules on cross-border conversions and cross-border divisions are huge step towards (finally) harmonised legal framework for cross- border business operations resulting with companies' migration.

If the Proposal eventually gets accepted, in proposed form or in improved form, procedure of companies' migration on EU level will be more harmonised, accelerated and hopefully cheaper.

\section{References}

Aksamovic, D., Simunovic, L. Kuna, I. (2019). 'Cross-border movement of companies: The new rules on cross-border conversion' in Proceedings of the $3^{\text {nd }} \mathrm{EU}$ and Comparative Law Issues and Challenges Series (Osijek, Croatia, June 6-7, 2019). EU and Comparative Law Issues and Challenges Series-Issue 3, Josip Juraj Strossmayer Univeristy, Faculty of Law Osijek, Croatia, DOI=https://www.pra vos.unios.hr/eu-and-comparative-law-issues-and-challenges-series.

Alvarez, S., (2018). 'The Commission's Company law Package: overview and critical view of the proposal for cross-border transactions', in European Law Blog, News and Comments on EU Law June 7, 2018. DOI= https://europeanlawblog.eu/20 18/06/07/the-commissions-company-law-package-overview-and-critical-view-ofthe-proposal-for-cross-border-transactions/

Biermeyer, T. \& M. Meyer (2018a). Cross-border Corporate Mobility in the EU: Empirical Findings 2018. Maastricht: Maastricht University.

Biermeyer, T. \& M. Meyer (2018b). 'Chaos day and tragedy in EU legislation making cross-border corporate mobility?' in Maastricht Journal of European Comparative Law, 25:3-6. https://doi.org/10.1177/1023263X18767801

Cerioni, L. (2010). 'The "abuse of rights" in EU Company and EU Tax Law: A re-reading of the ECJ Case Law and quest for a unitary notion' in European Business Law Review, 21(6):783-813. 
Cross-border transfer of company seats (2012). European Parliament resolution of 2 February 2012 with recommendations to the Commission on a 14th company law directive on the cross-border transfer of company seats (2011/2046(INI)) ANNEX, OJ C 239E, 20.8.2013, pp. 18-23.

EAVA (2012). Directive on the cross-border transfer of a company's registered office 14th Company Law Directive, European Added Value Assessment 3/2012, European Parliament (EAVA 3/2012).

Ernst \&Young (2018). Assessment and qualification of drivers, problems and impacts related to cross-border transfers of registered offices and cross-border divisions of companies. DG JUST, JUST/2015/PR/01/0003 (February 2018).DOI= https:// ec.europa.eu/info/sites/info/files/dg_just_transfers_divisions_final_report_05022 018_clean_1.pdf

European Commission, Feedback Statement (2013). Summary of Responses to the Public consultation on Cross-border transfers of registered office of companies, September 2013, Ref. Ares 158996-12/01/2016.

Frada de Sousa, A., (2009). Company's Cross-border Transfer of Seat in the EU after Cartesio, Jean Monnet Working Paper (New York University, School of Law 07/ 2009).

Frost, C. (2005). 'Transfer of Company's Seat -An Unfolding Story in Europe' in 36 VUWLR 36: 359-387. DOI=https://www.victoria.ac.nz/law/research publications /vuwlr/prev-issues/vol-36-2/frost.pdf

Horak, H. \& K. Dumančić (2017). 'Cross-Border Transfer of the Company Seat: One Step Forward, Few Steps Backward' in US-China L. Rev. 14:711-728.

Knapp, V. (2018). 'Cross-border mobility: what do we need in practice?' in Journal of the Academy of European Law, 19:63-76.

Lennarts, M.L. (2008). 'Company Mobility within the EU, fifty years on. From a nonissue to a hot topic' in Utrecht Law Review 4(1):1-5.

Mörsdorf, O. (2019). 'Der Entwurf einer Richtlinie für grenzüberschreitende Umwandlungen - Meilenstein oder Scheinriese?' in EuZW 2019:141-148. DOI= https://beckonline.beck.de

Frazzani, S., Angelici, C., Hoffmann, J., MmedicI, J. \& F. Sciaudone (2018). Polbud judgement and the freedom of establishment for companies in the European Union: problems and perspectives. Policy Department for Citizens' Rights and Constitutional Affairs, DG for Internal Policies if the Union, Study for the JURI Committee. European Union. p. 25.

http://www.europarl.europa.eu/supporting-analyses

Proposal (2017) for a Directive of the European Parliament and of the Council amending Directive (EU) 2017/1132 as regards cross-border conversions, mergers and divisions COM/2018/241 final - 2018/0114 (COD).

Proposal (1997) (COMXV/D2/6002/97) of November 1997 for a Fourteenth European Parliament and Council Directive on the Transfer of the Registration Office of a Company from one Member State to another with a Change of Applicable Law.

Rammeloo, S. (1999). 'Cross-border company Mobility and the Proposal for a 14th EC Company Law Directive: Daily Mail surmounted' in Maastricht Journal of European and Comparative Law, 6(2):105-110.

Rammeloo, S. (2018). 'Cross-border company migration in the EU: Transfer of registered office-the last piece of the Puzzle? Case C-106/16 Polbud, EU:C:2017: 804' in Maastricht Journal of European and Comparative law 25:87-107.

Study on the Application on the Cross-Border Mergers Directive (2013), Bech-Bruun Lexidale, September 2013, p. 5. DOI=https://publications.europa.eu/en/publicationdetail/-/publication/0291c60a-df7a-11e5-8fea-01aa75ed71a1. 
Third Council Directive (1978). 78/855/EEC of 9 October 1978 based on Article 54 (3) (g) of the Treaty concerning mergers of public limited liability companies OJ L 295, 20.10.1978, pp. 36-43.

Wymeersch, E. (2003). 'The transfer of the Company's seat in European Company Law' in Common Market Law Review 40(3):661-695.

\section{Cases}

Centrols Ltd and Erhvervs-og Selskabsstyrelsen, Case C212/97, ECR, I-1459. Judgement of 9 March 1999.

Polbud - Wykonawstwo sp. z o.o., Case C-106/16, Judgment of the Court (Grand Chamber) of 25 October 2017, ECLI:EU:C:2017:804, https://eur-lex.europa.eu/le gal-content/EN/TXT/PDF/?uri=CELEX:62016CJ0106

The Queen v H. M. Treasury and Commissioners of Inland Revenue, ex parte Daily Mail and General Trust plc. Case 81/87. European Court Reports 1988 -05483. ECLI identifier: ECLI:EU:C:1988:456 